\title{
Matrix metalloproteinases (MMPs) and inhibitor of metalloproteinases (TIMP) mRNA and protein expression in laryngeal squamous cell carcinoma
}

\author{
Weronika Lucas Grzelczyk ${ }^{1}$, Artur Wróbel-Roztropiński², Janusz Szemraj ${ }^{3}$, Magdalena Cybula ${ }^{3}$, \\ Wioletta Pietruszewska ${ }^{1}$, Bogna Zielińska-Kaźmierska², Magdalena Jozefowicz-Korczynska ${ }^{1}$
}

\author{
${ }^{1}$ Department of Otolaryngology, Medical University of Lodz, Norbert Barlicki Memorial \\ Teaching Hospital, Lodz, Poland \\ ${ }^{2}$ Department of Cranio-Maxillofacial and Oncological Surgery, Norbert Barlicki \\ Memorial Teaching Hospital, Lodz, Poland \\ ${ }^{3}$ Department of Medical Biochemistry, Medical University of Lodz, Lodz, Poland
}

Submitted: 17 February 2017

Accepted: 25 March 2017

Arch Med Sci 2019; 15 (3): 784-791

DOI: https://doi.org/10.5114/aoms.2017.72405

Copyright @ 2019 Termedia \& Banach

\begin{abstract}
Introduction: The aim of the study was to investigate the mRNA expression and protein levels of matrix metalloproteinases (MMP) 2 (MMP-2), 9 (MMP-9), 7 (MMP-7) and their tissue inhibitor TIMP-2 in patients with laryngeal squamous cell carcinoma and control subjects and additionally to evaluate a possible correlation with clinicopathological features.

Material and methods: The expression levels of MMP-2, MMP-9, MMP-7, and TIMP-2 mRNA were detected by the real-time quantitative real time polymerase chain reaction method in 96 cases of laryngeal carcinoma vs. non-tumor tissue. The blood serum levels of MMP-2, MMP-9, MMP-7, and TIMP-2 in patients with laryngeal cancer and 100 healthy subjects were measured using the enzyme-linked immunosorbent assay (ELISA) method. Results: The present study demonstrated that MMP-2, MMP-7, MMP-9 and TIMP-2 mRNA expression levels in carcinoma tissue vs. non-tumor tissue and protein levels in the preoperative serum vs. those obtained in healthy controls were statistically significantly higher than in the healthy controls $(p=0.001)$. The only significant correlation between mRNA or concentration of measured MMPs and TIMP and the clinicopathological features was found for TIMP-2 protein and for patients with lymph node metastasis. Serum levels of TIMP-2 were higher in cases with lymph node metastasis than in those without lymph node metastasis $(p<0.05)$.

Conclusions: The results may suggest that MMPs and TIMP-2 are associated with laryngeal tumorigenesis, but we did not find any distinct correlation between the clinicopathological features of laryngeal squamous cell carcinoma patients and expression levels of MMPs and TIMP. The results suggest that the measurement of serum MMP-2, MMP-7, MMP-9 and TIMP-2 concentration might be helpful to diagnose laryngeal squamous cell carcinoma.
\end{abstract}

Key words: matrix metalloproteinase, laryngeal cancer, tissue inhibitor of metalloproteinase.

\section{Introduction}

Head and neck squamous cell carcinomas (HNSCCs) are characterized by an aggressive growth pattern and early metastatic spread [1]. Laryngeal cancer is the $20^{\text {th }}$ most common cancer in Europe, with around 39,900

\author{
Corresponding author: \\ Dr. Weronika Lucas Grzelczyk \\ Department \\ of Otolaryngology \\ Medical University \\ of Lodz \\ 22 Kopcinskiego St \\ Lodz, Poland \\ Phone: +48 517789311 \\ E-mail:weronika.lucas@ \\ gmail.com
}


new cases diagnosed in 2012 (1\% of the total) [2]. Laryngeal carcinoma is the second most common malignancy of the head and neck worldwide [3]. The incidence is also higher in males than in females with predominant histological squamous cell carcinoma type [4]. Survival rates of laryngeal cancer patients range from $73 \%$ to $92 \%$ for early disease stage (I and II) and from 50\% to 64\% for advanced disease stage (III and IV) [4]. The diagnosis of neck lymph node metastases is an essential requirement for clinical staging and treatment, and is now widely accepted as the most important factor in HNSCC prognosis [5]. Despite improvements in diagnostic and therapeutic techniques and therapy, the 5-year survival rates for patients with laryngeal squamous cell carcinoma (LSCC) have not increased over the last 20 years [6].

The most important risk factors are smoking, alcohol consumption and human papillomavirus (HPV) infection [7, 8].

Carcinogenesis of head and neck tumors is a process of multiple steps, in which there are genetic effects that lead to deregulation of cell metabolism. The development of local regional and distant metastases begins with the initiation of the primary tumor and ends with the establishment of metastatic clones throughout the host. Several processes including the differential expression of cell adhesion molecules, release of matrix metalloproteinases (MMPs), and angiogenesis occur at multiple points in the metastatic cascade [9].

Numerous reports have shown that MMPs are directly implicated in almost every biological process, involving matrix remodeling throughout the mammalian life span, from embryo implantation to cell death or necrosis [10]. The MMPs have been implicated in the physiological and pathological remodeling of the tissues. They belong to a family of proteases known as the metzincin superfamily. Extracellular matrix (ECM) is degraded by various proteases, the MMP family having a pivotal role. Numerous studies have indicated that MMPs (including MMP-7 and especially gelatinases) and their respective tissue inhibitors have an important role in carcinogenesis $[1,11]$. For example, both MMP-2 and MMP-9 degrade cleaved collagen more efficiently than other gelatinolytic MMPs, and MMP-7 is a more potent proteoglycanase than MMP-9 [12].

These enzymes (MMPs) are associated with tumor cell invasion of the basement membrane and stroma, blood vessel penetration, and metastasis [13].

The activity of these enzymes is tightly regulated in a number of ways, such as transcriptional regulation, proteolytic activation, and interaction with tissue inhibitors of metalloproteinases (TIMPs) [14]. A family of tissue inhibitors of TIMPs is capable of inhibiting fully activated MMPs, and the local balance between MMPs and TIMPs seems to be crucial in the control of tumor invasion and metastasis. The most studied of these inhibitors are TIMP-1 and TIMP-2 [11]. The expression and involvement of several MMPs and TIMPs in LSCC have been determined in several studies. However, these studies showed relatively conflicting results concerning their contribution to the clinicopathological findings and prognosis of the patients with LSCC [15-29]. Clinical trials effectively evaluating the benefit of novel treatment options, as well as the identification of novel therapeutic targets and molecular markers, are needed to improve the survival and quality of life of LSCC patients [3, 5].

The aim of the present study was to investigate the mRNAs and protein expression of MMP-2, MMP-9, MMP-7, and their tissue inhibitor TIMP-2 in patients with laryngeal squamous cell carcinoma and control subjects and additionally to evaluate a possible correlation with clinicopathological features.

\section{Material and methods}

\section{Characteristics of study groups}

The study group consisted of 96 (15 women and 81 men) patients with laryngeal squamous cell cancer, aged between 48 and 82 years, mean $62 \pm 8.0$ years. All of the patients were treated surgically at the Department of Otolaryngology in the period 2012-2015; only patients without any history of previous radio- or chemotherapy were included. The primary tumor size and stage were classified according to the Union for International Cancer Control (UICC) and the American Joint Committee on Cancer (AJCC) [30, 31] (Table I).

In order to evaluate the impact of the variables on the results of the mRNA and protein expression of MMP-2, MMP-9, MMP-7 and their tissue inhibitor TIMP-2, the patients were assessed with respect to sex (female, male); age (younger group - up to 65 years of age, older group - over 65 years of age); primary tumor size (T1, T2 vs. $\mathrm{T3}, \mathrm{T4}$ ); lymph node status (NO - negative vs. $\mathrm{N+}$ positive), histopathological staging (G1, G2, G3), clinical stage (I, II vs. III, IV), location of the carcinoma, and smoking duration (all the investigated patients were smokers from 20 to 100 pack-year smoking, mean $44 \pm 17$ pack-year smoking).

The study design was approved by the Ethics Committee (RNN/203/13/KE).

\section{Sample collection}

Paired tissue samples of tumor and normal tissues were obtained from all surgically treated patients. After surgery, the samples were preserved 
Table I. Characterization of the patients with laryngeal cancer $(n=96)$

\begin{tabular}{|c|c|}
\hline Feature & No. of patients (\%) \\
\hline \multicolumn{2}{|l|}{ Sex: } \\
\hline Female & $15(16)$ \\
\hline Male & $81(84)$ \\
\hline \multicolumn{2}{|l|}{ Age: } \\
\hline$<65$ & $67(70)$ \\
\hline$>65$ & $29(30)$ \\
\hline \multicolumn{2}{|l|}{ Primary tumor size $(T)$ : } \\
\hline $\mathrm{T} 1$ & $16(17)$ \\
\hline $\mathrm{T} 2$ & $12(12)$ \\
\hline T3 & $20(21)$ \\
\hline $\mathrm{T} 4$ & $48(50)$ \\
\hline \multicolumn{2}{|l|}{ Nodal involvement $(\mathrm{N})$ : } \\
\hline Negative & $71(74)$ \\
\hline Positive & $25(26)$ \\
\hline \multicolumn{2}{|l|}{ Histopathology grade: } \\
\hline Well differentiated & $9(9)$ \\
\hline Moderately differentiated & $75(78)$ \\
\hline Poorly differentiated & $12(13)$ \\
\hline \multicolumn{2}{|l|}{ Clinical stage: } \\
\hline I & 18 (19) \\
\hline II & $9(9)$ \\
\hline III & $24(25)$ \\
\hline IV & $45(47)$ \\
\hline \multicolumn{2}{|l|}{ Localization: } \\
\hline Supraglottic & $29(30)$ \\
\hline Glottic & $45(47)$ \\
\hline $\begin{array}{l}\text { Supraglottic, } \\
\text { glottic and subglottic }\end{array}$ & $21(22)$ \\
\hline Subglottic & $1(1)$ \\
\hline Transglottic & $30(31)$ \\
\hline
\end{tabular}

and stored at $-80^{\circ} \mathrm{C}$. The tumor specimen was taken from the center of the tumor tissue. Normal tissue was used as the control. The adjacent normal tissues were used when the tissues were about $1.5-2 \mathrm{~cm}$ from the tumor border and were diagnosed as not having precancerous or cancerous lesions. The diagnosis of laryngeal cancer tissues was made by pathologists based on the histological analysis of tumor biopsies. All laryngeal carcinoma samples were pathologically confirmed as laryngeal squamous cell carcinoma.
Blood samples from all the patients and from 100 healthy subjects were drawn before the surgical treatment and were allowed to clot before centrifugation. The control group consisted of 100 healthy subjects (47 women and 53 men), aged between 49 and 84 years, mean $65.5 \pm 7.5$ years. Sera were removed, aliquoted and stored at $-80^{\circ} \mathrm{C}$ until assayed.

\section{RNA extraction and reverse transcriptase polymerase chain reaction}

Total RNA was extracted from frozen tissues using an RNA extraction reagent, TRIZOL (Invitrogen Life Technologies), according to the standard acid-guanidinium-phenol-chloroform method. The extracted RNA was analyzed by agarose gel electrophoresis and only cases with preserved 28S, $18 \mathrm{~S}$ and $5 \mathrm{~S}$ ribosomal RNA bands indicating good RNA quality were used in the study. Total RNA was digested with DNase I (Gibco) at room temperature for $15 \mathrm{~min}$. Five micrograms of digested RNA were reversely transcribed at $42^{\circ} \mathrm{C}$ for $60 \mathrm{~min}$ in a total $20 \mathrm{ml}$ reaction volume using the ImProm-II Reverse Transcription System kit (Promega, USA). The obtained CDNA was used in the real-time PCR reaction. Real-time PCR based on TaqMan technology was performed using a master mix prepared according to the FastStart Universal Probe Master (ROX) from Roche Applied Science. Probes and primers were designed using the online Universal ProbeLibrary.

Real-time PCR was carried out in a final volume of $50 \mu \mathrm{l}$, with $0.05 \mu \mathrm{g}$ cDNA, $25 \mu$ FastStart Universal Probe Master (ROX) 2x, $250 \mathrm{nM}$ probe and $1 \mu \mathrm{M}$ of each primer. Amplification was performed for $10 \mathrm{~min}$ at $95^{\circ} \mathrm{C}$ to activate FastStart Taq DNA polymerase and 40 rounds of $15 \mathrm{~s}$ at $95^{\circ} \mathrm{C}$ and $1 \mathrm{~min}$ at $60^{\circ} \mathrm{C}$ for amplification and signal analysis. ABI Prism 7000 Sequence Detection System from Applied Biosystems was used to detect amplifications. Each sample was assayed in triplicate in independent reactions. Real-time PCR data were automatically calculated with the data analysis module. The results were analyzed according to the $2^{-\Delta \Delta C t}$ method. Validation of PCR efficiency was performed with a standard curve. Standard curves were prepared for each gene by serial dilution.

\section{Protein analyses}

For the quantitative detection of human serum MMP-2,-7,-9 and TIMP-2, the RayBio Human ELISA (enzyme-linked immunosorbent assay) from RayBiotech was used. Each serum sample was determined three times. Instructions and calculations of results were performed according to the manufacturer's recommendations. Standards and samples were pipetted into the wells with the immo- 
bilized antibody specific for human MMP-2, -7, -9 and TIMP-2, and incubated. After incubation and washing, the biotinylated antihuman MMP-2, -7, -9 and TIMP-2 antibody was added. After washing away any unbound substances and the biotinylated antibody, horseradish peroxidase-conjugated streptavidin was pipetted into the wells. The wells were again washed, a tetramethylbenzidine (TMB) substrate solution was added to the wells and color developed in proportion to the amount of MMP-2, -7, -9 and TIMP-2 bound. The color development was stopped (Stop Solution) and the intensity of the color was measured by the Thermo Labsystems Multiskan Ascent 354 from Lab Recyclers at $450 \mathrm{~nm}$.

\section{Statistical analysis}

The data were described by means of simple descriptive statistics: the mean and median value for location and standard deviation and range for dispersion of quantitative data (protein concentration, gene expression) as well as the sample fraction for description of qualitative variables.

In statistical inference, non-parametric tests of significance were used (Wilcoxon test for paired data, Mann-Whitney $U$ test for comparison of distributions in two independent groups).

Associations between covariates of interest were qualified by means of Spearman rank correlation coefficients. In all the analyses, the statistical significance was considered attained for $p \leq 0.05$. All the calculations were derived by means of Statistica v12.0 software.

\section{Results}

\section{MMP and TIMP mRNA expression}

The gene expression of MMP-2, MMP-7, MMP-9, and TIMP-2 was investigated in laryngeal cancer tissues and normal tissues by RT-PCR. Mean values of gene expression of MMP-2, MMP-7, MMP-9 and TIMP-2 mRNA in the laryngeal cancer tissues were significantly higher than those in the normal tissues ( $p<0.001)$, (Table II, Figure 1 ).

In the present study, no significant relationship was found between the gene expression of MMP-2, MMP-7, MMP-9, TIMP-2 mRNA and clinicopatho- logical features of LSCC patients, such as T stage, $\mathrm{N}$ stage, clinical stage, and histological grade.

Moreover, no association was observed between the patients' age and sex or location of carcinoma and smoking duration.

\section{Serum levels of MMP and TIMP}

The pretreatment serum levels of MMP-2, MMP-7, MMP-9, and TIMP-2 were quantitatively measured by ELISA assay. The results were compared with the clinicopathological factors of the disease. Protein concentrations of MMP-2, MMP-7, MMP-9 and TIMP-2 were significantly higher in the sera of the laryngeal cancer patients than in healthy subjects $(p<0.001)$ (Table III, Figure 2$)$.

There were no statistically significant differences between serum levels of MMP-2, MMP-7, MMP-9 and the clinicopathological features of the disease concerning $T$ stage, $N$ stage, clinical stage, and differentiation, however with one exception: serum TIMP-2 levels were higher in the patients with lymph node metastasis than in those without lymph node metastasis, $113 \pm 52 \mathrm{ng} / \mathrm{ml}$ (N0) vs. $146 \pm 88 \mathrm{ng} / \mathrm{ml}(\mathrm{N} 1), p<0.05$.

No association was observed between the age, sex of patients or location of the carcinoma and smoking duration.

\section{Discussion}

In our series of 96 patients with laryngeal cancer, we found that the MMP mRNA gene expression in the tumor tissues is significantly higher than that in the normal tissues. We also observed that the serum levels of MMP proteins in these patients are significantly higher than those in healthy subjects, which suggests that they could be upregulated in tumorigenesis. Similar results were obtained in a few previous studies. The MMP expression was reported to be higher in the tumor tissue compared to the adjacent non-neoplastic tissues [15-17]. Xie et al. [16], in a study including thirty-two patients, showed that both mRNA and protein expression levels of MMP-2, MMP-7 and MMP-9 were increased in supraglottic carcinoma tissue samples as compared to matched normal tissues and were significantly correlated with lymph node metastasis.

Table II. mRNA expression of MMPs and TIMP in laryngeal tumor vs. non-tumor tissue (data presented as mean $\pm \mathrm{SD}$ )

\begin{tabular}{|lccc|}
\hline MMP & Tumor tissue & Non-tumor tissue & $P$-value \\
\hline MMP-2 & $0.31 \pm 0.10$ & $0.09 \pm 0.03$ & $<0.001$ \\
\hline MMP-7 & $0.24 \pm 0.08$ & $0.12 \pm 0.04$ & $<0.001$ \\
\hline MMP-9 & $0.30 \pm 0.14$ & $0.13 \pm 0.04$ & $<0.001$ \\
\hline TIMP-2 & $0.26 \pm 0.08$ & $0.12 \pm 0.03$ & $<0.001$ \\
\hline
\end{tabular}


A

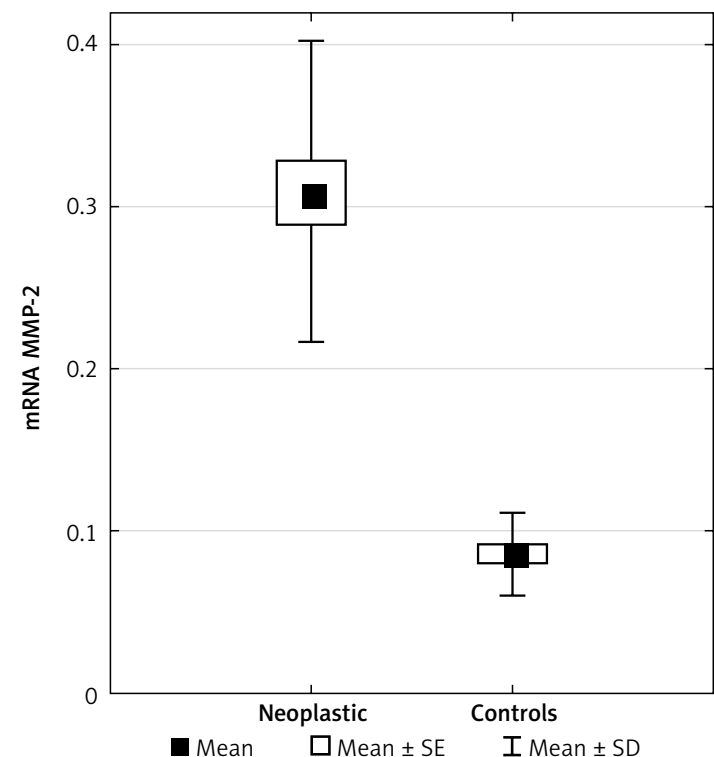

C

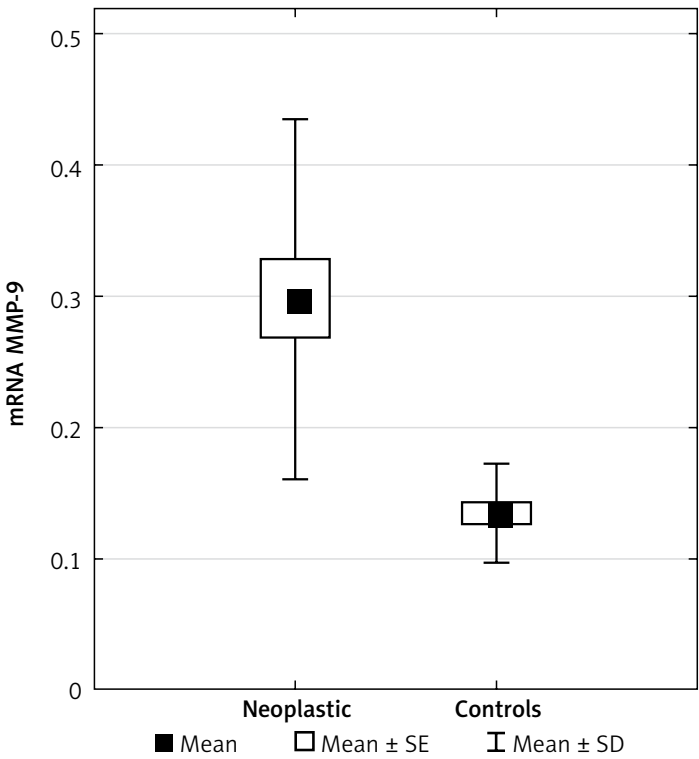

B

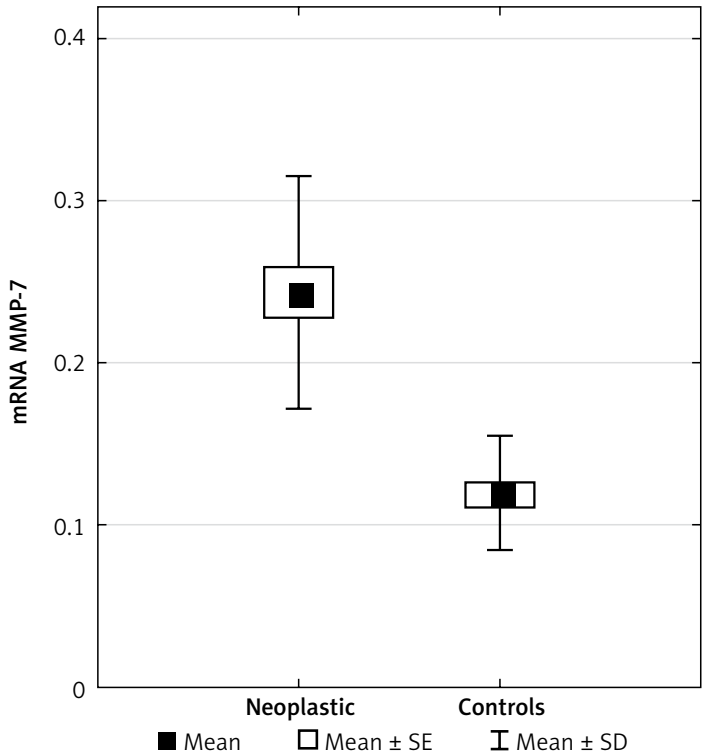

D

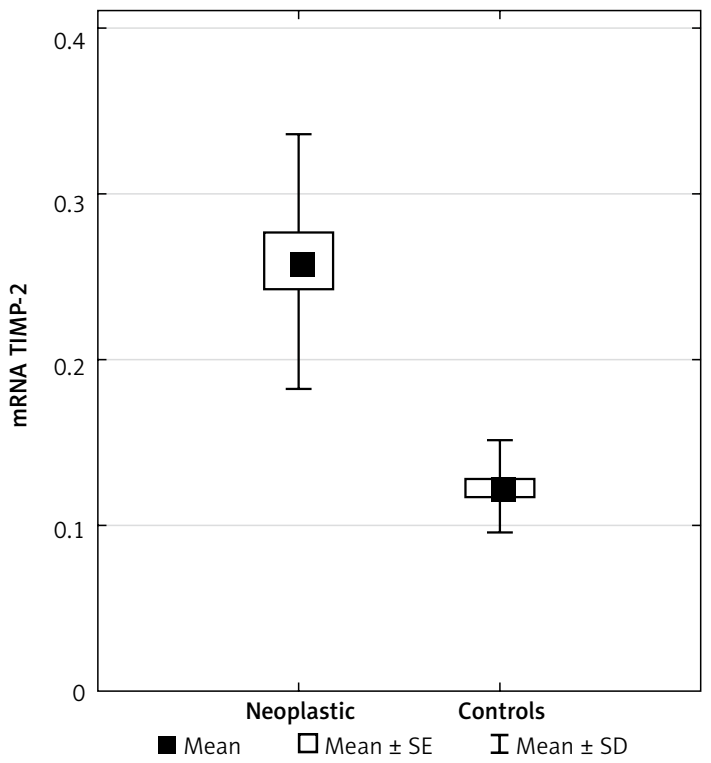

Figure 1. Distributions of mRNA expression of MMPs and TIMP in laryngeal tumor (neoplastic) vs. non-tumor tissue (controls) presented as mean with standard error (SE) and standard deviation (SD)

Table III. Distributions of protein concentrations in serum in laryngeal cancer and healthy subjects

\begin{tabular}{|lccc|}
\hline MMP & Laryngeal cancer $[\mathrm{ng} / \mathrm{ml}]$ & Healthy subjects $[\mathrm{ng} / \mathrm{ml}]$ & $P$-value \\
\hline MMP-2 & $909 \pm 225$ & $495 \pm 89$ & $<0.001$ \\
\hline MMP-7 & $244 \pm 50$ & $144 \pm 31$ & $<0.001$ \\
\hline MMP-9 & $313 \pm 91$ & $171 \pm 31$ & $<0.001$ \\
\hline TIMP-2 & $122 \pm 64$ & $59 \pm 17$ & $<0.001$ \\
\hline
\end{tabular}

In our study, no significant relationship was found between both mRNA and protein expression of MMP-2, MMP-7, MMP-9 and the clinicopathological features, such as histological grade, primary site, $\mathrm{T}$ stage, $\mathrm{N}$ stage, and clinical stage in LSCC patients. The data from the literature are diverse in this issue. The current study results are consistent with those achieved by Liu et al. [18], who, in a retrospective study of 72 LSCC patients, did not find any clinical and pathological correla- 
A

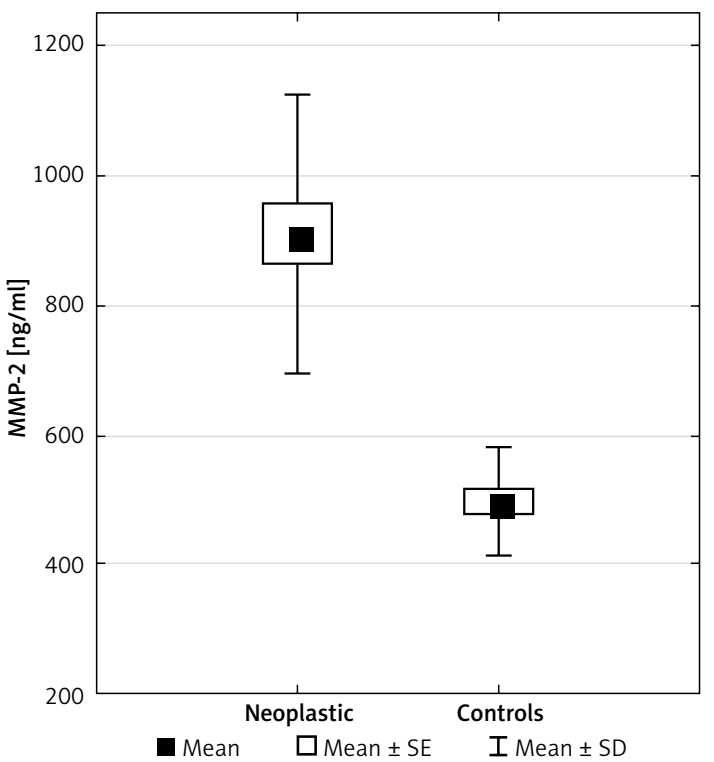

C

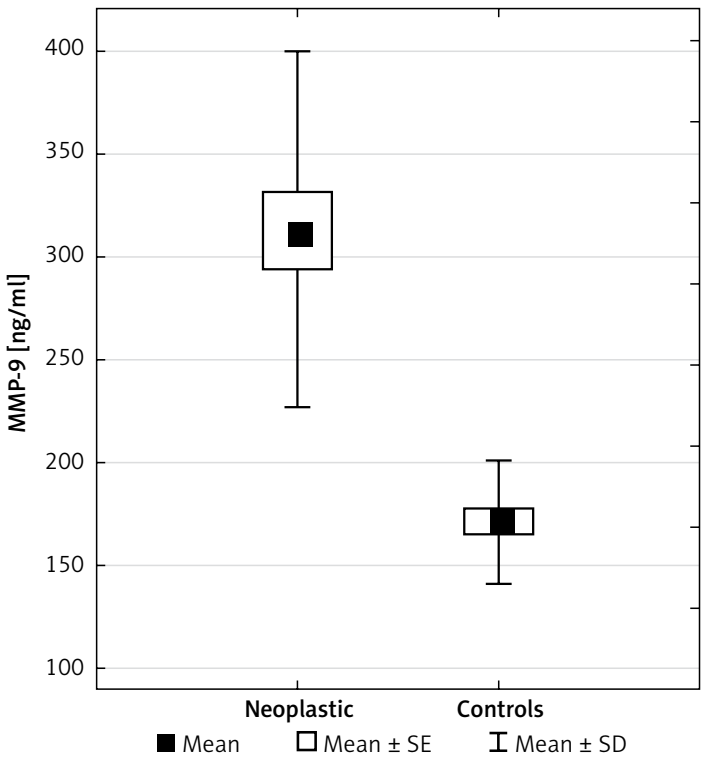

B

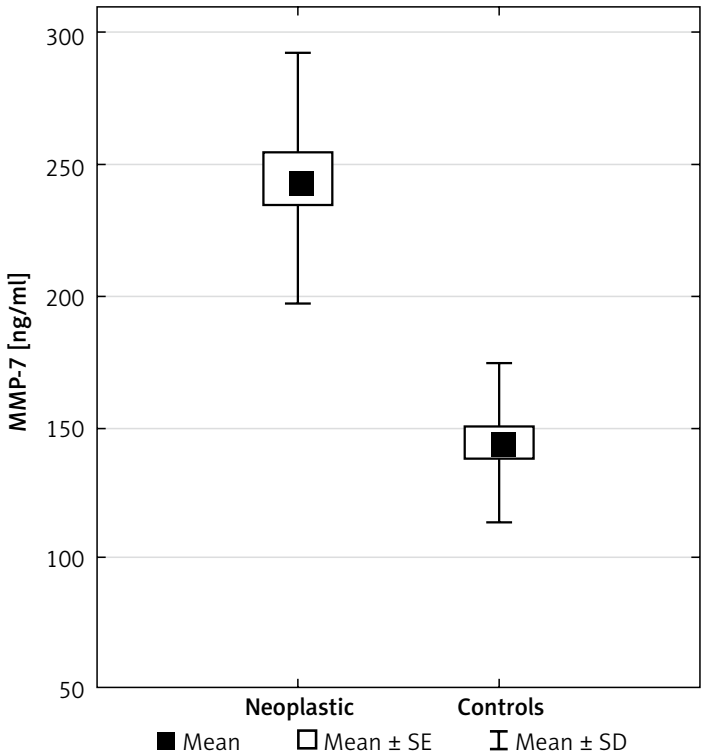

D

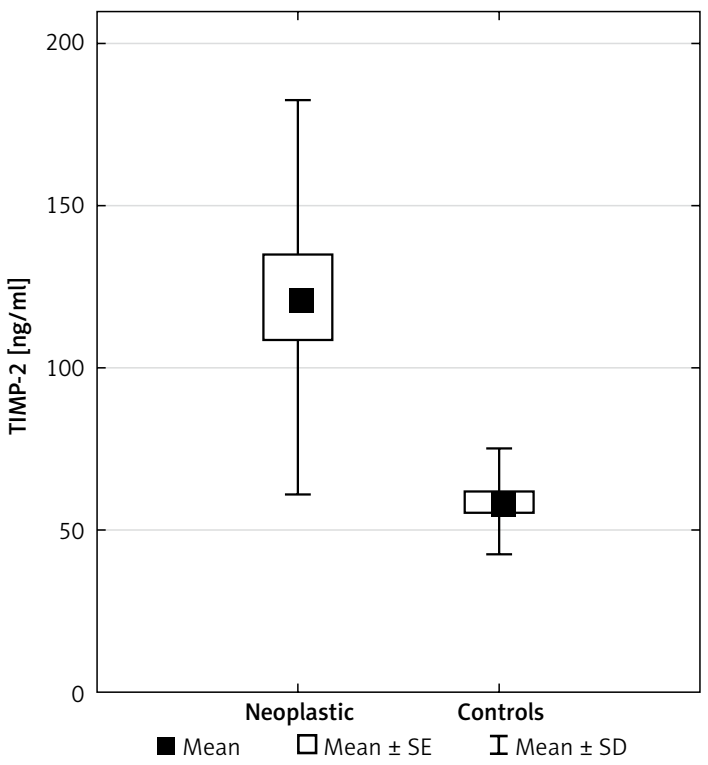

Figure 2. Distributions of protein concentration in serum in laryngeal cancer (neoplastic) and healthy subjects (controls) presented as mean with standard error (SE) and standard deviation (SD)

tions in protein expression of MMP-2 and MMP-9. Similarly, Krecicki et al. [19] did not indicate any significant correlation between MMP-2 protein expression and clinicopathological factors, e.g. histological grading, T category and nodal status. Moreover, Görögh et al. [32] estimating MMP-9 expression and metastasis formation or tumor size in HNSCC achieved similar results.

We studied serum levels of MMP-2, MMP-7, MMP-9 and TIMP-2 and found that they were significantly higher in the samples of laryngeal squamous cell carcinoma tissues than in controls. In our research, the only significant correlation between concentrations of measured MMPs and TIMP and the clinicopathological features was detected for
TIMP-2 protein and for patients with lymph node metastasis. Serum levels of TIMP-2 were higher in cases with lymph node metastasis than in those without it $(p<0.05)$.

To our knowledge, there are few papers in the literature on the MMP and TIMP expression levels in the sera of patients with LSCC [23, 24, 26, 29].

Lofti et al. [26], in a study including 20 patients, found that serum levels MMP-2 and MMP-9 were increased with the T stage compared with the healthy controls and MMP-2 was positively correlated with lymph node metastases. Another study investigated the pre-treatment and post-treatment gelatinase serum levels in 49 patients and showed a significant gradual decrease 
after treatment for pro-MMP-9, showing a possible role of this molecule as a tumor marker in laryngeal cancer [29].

In our study, all the patients we investigated were smokers, and most of them have at least a 30 pack-year smoking history. Cigarette smoke is thought to cause upregulation of MMPs. Especially MMP-9 has been implicated to be elevated in smoking status [33, 34]. The correlation between elevated serum levels of MMPs and smoking was not confirmed in our study. Similarly, Kalfert et al. [23] found no association between preoperative serum levels of MMP-2, MMP-9 and smoking habit in patients with laryngeal cancer, although they found a correlation between serum levels of MMP-1 and smoking habit in laryngeal cancer patients but not in oropharyngeal and hypopharyngeal cancer. These authors suggest that MMP-1 might represent the most important regulator of the cancer pathway in laryngeal cancer in smokers.

Furthermore, in the present study, the mRNA and protein expression of TIMP-2 did not depend on the tumor ( $T$ classification). Other research showed that the expression level of TIMP-2 in tissue increased with increasing cancer stage, thus suggesting the possible post-transcriptional removal of its mRNA [20]. On the other hand, Görögh et al. [32] reported TIMP-2 to be negatively correlated with lymph node metastases or tumor size in HNSCC, suggesting that TIMP-2 suppresses cancer spread in LSCC. However, Danilewicz et al. [22] evaluated the relationship between the expression of TIMP-2 and the presence or absence of lymph node metastases in LSCC and no correlation was substantiated.

Some authors have stated that high MMP expression is associated with clinicopathological features $[16,20,21,25,28]$ and poor prognosis in laryngeal cancer patients, suggesting that this parameter could be used as a potential predictor [18, 22, 21, 27]. Liu et al. [25], in a meta-analysis including 48 English and 38 Chinese, reporting on 529 patients with laryngeal cancer, demonstrated that the high expression of MMP-2 protein in laryngeal cancer has a significant correlation with the tumor differentiation level and cervical lymph node metastasis. Wiegand et al. [35], in their meta-analysis (14 studies performed in 710 patients) on MMP-2 and metastases in lymph nodes in patients with HNSCC, found that MMP-2 possibly played a role in the metastatic behavior of HNSCC tumors.

MMP-2 and MMP-9 expression levels have been reported in a number of human cancer cell lines and various human tumors including those of the ovary, breast, liver, bladder, skin, head and neck, uterine cervix, and lungs $[1,9,36]$ and also have been reported in several disease conditions including coronary heart disease [37].
Matrix metalloproteinases (MMPs) can regulate the tumor microenvironment, and their expression and activation are increased in almost all human cancers compared with normal tissues [38].

The importance and ubiquity of biological roles of MMPs strongly suggest that MMP deregulation is an important pathogenic factor in many diseases and so too remains a promising vista for drug targeting [10].

We used two different laboratory techniques, QRT- PCR and ELISA, to measure the tissue expression and serum levels of MMP-2, MMP-7, MMP-9 and TIMP-2. The MMPs that have been most extensively measured in LSCC in a number of studies are the gelatinases MMP-2 and MMP-9, and most of these studies have used immunohistochemistry, reverse transcription polymerase chain reaction, in situ hybridization and gelatin zymography. The majority of publications concentrated on expression in the stroma. All these techniques show different analytical sensitivities so that different expression patterns could also reflect a higher or lower sensitivity of the procedures applied [39].

In conclusion, the present study demonstrated that MMP-2, MMP-7, MMP-9, and TIMP-2 protein levels in the preoperative serum and mRNA expression in the laryngeal squamous cell carcinoma tissue were higher than in the healthy controls. These results may suggest that MMPs and TIMP are associated with laryngeal tumorigenesis. However, we did not find a clear correlation between the clinicopathological features of laryngeal cancer patients and expression levels of MMPs and TIMP. The results suggest that the measurement of serum MMP-2, MMP-7, MMP-9 and TIMP-2 concentrations might be helpful to diagnose laryngeal squamous cell carcinoma.

\section{Conflict of interest}

The authors declare no conflict of interest.

\section{References}

1. Hong SD, Hong SP, Lee JI, Lim CY. Expression of matrix metalloproteinase-2 and -9 in oral squamous cell carcinomas with regard to the metastatic potential. Oral Oncol 2000; 36: 207-13.

2. Ferlay J, Steliarova-Foucher E, Lortet-Tieulent J, et al. Cancer incidence and mortality patterns in Europe: estimates for 40 countries in 2012. Eur J Cancer 2013; 49: 1374-403.

3. Mäkitie AA, Monni O. Molecular profiling of laryngeal cancer. Expert Rev Anticancer Ther 2009; 9: 1251-60.

4. Khoueir N, Matar N, Farah C, Francis E, Tabchy B, Haddad A. Survival of T4aNO and T3N+ laryngeal cancer patients: a retrospective institutional study and systematic review. Am J Otolaryngol 2015; 36: 755-62.

5. Polanska H, Raudenska M, Gumulec J, et al. Clinical significance of head and neck squamous cell cancer biomarkers. Oral Oncol 2014; 50: 168-77. 
6. Li M, Tian L, Ren H, et al. MicroRNA-101 is a potential prognostic indicator of laryngeal squamous cell carcinoma and modulates CDK8. J Transl Med 2015; 13: 271.

7. Vojtechova Z, Sabol I, Salakova M, et al. Comparison of the miRNA profiles in HPV-positive and HPV-negative tonsillar tumors and a model system of human keratinocyte clones. BMC Cancer 2016; 16: 382.

8. Józefowicz-Korczyńska M, Mazerant M, Morshed K, Olejniczak I, Bojanowska-Poźniak K. Wstępna ocena zależności pomiędzy zakażeniem HPV a wybranymi cechami nowotworu u chorych na raka krtani. Otorynolaryngologia 2014; 13: 155-62.

9. Petruzzelli, Guy J. The biology of distant metastases in head and neck cancer. ORL J Otorhinolaryngol Relat Spec 2001; 63: 192-201.

10. David Rodríguez D, Morriso CJ, Overall CM. Matrix metalloproteinases: what do they not do? New substrates and biological roles identified by murine models and proteomics. Biochim Phiophys Acta 2010; 1803: 139-54.

11. de Vicente JC, Lequerica-Fernandez P, Santamaria J, Fresno MF. Expression of MMP-7 and MT1-MMP in ora squamous cell carcinoma as predictive indicator for tumor invasion and prognosis. J Oral Pathol Med 2007; 36: 415-24.

12. Parks WC, Wilson CL, López-Boado YS. Matrix metalloproteinases as modulators of inflammation and innate immunity. Nat Rev Immunol 2004; 4: 617-29.

13. Nelson AR, Fingleton B, Rothenberg ML, Matrisian LM. Matrix metalloproteinases: biologic activity and clinical implications. J Clin Oncol 2000; 18: 1135-49.

14. Yamamoto K, Murph G, Troeberg L. Extracellular regulation of metalloproteinases. Matrix Biol 2015; 44-46: 255-63.

15. Kapral M, Strzałka-Mrozik B, Paluch J, Kowalczyk M, Jurzak M, Weglarz L. Evaluation of gene expression of selected matrix metalloproteinases and their tissue inhibitors in laryngeal cancer. Farm Przegl Nauk 2010; 10: 41-6.

16. Xie M, Sun Y, Li Y. Expression of matrix metalloproteinases in supraglottic carcinoma and its clinical implication for estimating lymph node metastases. Laryngoscope 2004; 114: 2243-8.

17. Zhang H, Liu M, Sun Y, Lu J. MMP-14 can serve as a prognostic marker in patients with supraglottic cancer. Eur Arch Otorhinolaryngol 2009; 266: 1427-34.

18. Liu WW, Zeng ZY, Wu QL, Hou JH, Chen YY. Overexpression of MMP-2 in laryngeal squamous cell carcinoma: a potential indicator for poor prognosis. Otolaryngol Head Neck Surg 2005; 132: 395-400.

19. Krecicki T, Zalesska-Krecicka M, Jelen M, Szkudlarek T, Horobiowska M. Expression of type IV collagen and matrix metalloproteinase-2 (type IV collagenase) in relation to nodal status in laryngeal cancer. Clin Otolarygol 2001; 26: 469-72.

20. Christopoulos TA, Papageorgakopoulou N, Ravazoula P, et al. Expression of metalloproteinases and their tissue inhibitors in squamous cell laryngeal carcinoma. Oncol Rep 2007; 18: 855-60.

21. Colović Z, Pesutić-Pisac V, Poljak NK, Racić G, Cikojević D, Kontić M. Expression of matrix metalloproteinase- 9 in patients with squamous cell carcinoma of the larynx. Coll Antropol 2013; 37: 151-5.

22. Danilewicz M, Sikorska B, Wagrowska-Danilewicz M. Prognostic significance of the immunoexpression of matrix metalloproteinase MMP2 and its inhibitor TIMP2 in laryngeal cancer. Med Sci Monit 2003; 9: 42-7.

23. Kalfert D, Ludvikova M, Topolcan O, et al. Analysis of preoperative serum levels of MMP1, -2 , and -9 in patients with site-specific head and neck squamous cell cancer. Anticancer Res 2014; 34: 7431-41.

24. Klisho E, Savenkova O, Kondakova I, Perel'muter V, Choĭnzonov E, Shishkin D. Assay of matrix metalloproteinase levels and their endogenous inhibitors in patients with laryngeal carcinoma. Vopr Onkol 2007; 53: 26-31.

25. Liu RR, Li MD, Li T, Tan Y, Zhang M, Chen JC. Matrix metalloproteinase 2 (MMP2) protein expression and laryngeal cancer prognosis: a metaanalysis. Int J Clin Exp Med 2015; 8: 2261-1.

26. Lotfi A, Mohammadi G, Saniee L, Mousaviagdas M, Chavoshi $\mathrm{H}$, Tavassoli A. Serum level of matrix metalloproteinase-2 and -9 in patients with laryngeal squamous cell carcinoma and clinical significance. Asian Pac J Cancer Prev 2015; 16: 6749-51.

27. Mallis A, Teymoortash A, Mastronikolis NS, Werner JA, Papadas TA. MMP-2 expression in 102 patients with glottic laryngeal cancer. Eur Arch Otorhinolaryngol 2012; 269: 639-42.

28. Papadas TA, Naxakis SS, Mastronikolis NS, Stathas T, Karabekos NC, Tsiambas E. Determination of matrix metalloproteinase 9 (MMP-9) protein expression in laryngeal squamous cell carcinomas based on digital image analysis. J BUON 2013; 18: 977-81.

29. Tsiropoulos G, Papadas T, Triantaphyllidou IE. Pre-treatment gelatinases serum levels and post-treatment changes in laryngeal cancer patients. Hippokratia 2013; 17: 220-7.

30. American Joint Committee on Cancer: AJCC; www.cancerstaging.org.

31. Union for International Cancer Control (UICC); www. uicc.org.

32. Görögh T, Beier UH, Bäumken J, et al. Metalloproteinases and their inhibitors: influence on tumor invasiveness and metastasis formation in head and neck squamous cell carcinomas. Head Neck 2006; 28: 31-9.

33. Palozza P, Simone RE, Catalano A, et al. Modulation of MMP-9 pathway by lycopene in macrophages and fibroblasts exposed to cigarette smoke. Inflamm Allergy Drug Targets 2012; 11: 36-47.

34. Snitker S, Xie K, Ryan KA, et al. Correlation of circulating MMP-9 with white blood cell count in humans: effect of smoking. PLoS One 2013; 25: e66277.

35. Wiegand S, Dünne AA, Müller $\mathrm{HH}$, et al. Metaanalysis of the significance of matrix metalloproteinases for lymph node disease in patients with head and neck squamous cell carcinoma. Cancer 2005; 104: 94-100.

36. Kato K, Hara A, Kuno T, et al. Matrix metalloproteinases 2 and 9 in oral squamous cell carcinomas: manifestation and localization of their activity. J Cancer Res Clin Oncol 2005; 131: 340-6.

37. Wu H, Shou X, Liang L, Yao X, Cheng G. Correlation between plasma angiopoietin-1, angiopoietin-2 and matrix metalloproteinase- 2 in coronary heart disease. Arch Med Sci 2016; 12: 1214-9.

38. Egeblad M, Werb Z. New functions for the matrix metalloproteinases in cancer progression. Nat Rev Cancer 2002; 2: 161-74.

39. Lichtinghagen $R$, Musholt PB, Lein $M$, et al. Different mRNA expression and protein expression of matrix metalloproteinases 2 and 9 and tissue inhibitor of metaloproteinases TIMP-1 in benign and malignat prostate tissue. Eur Urol 2002; 42: 398-406. 